\title{
STRATEGI DAKWAH BERBASIS SOCIAL NETWORK (TINJAUAN MAJELIS DAKWAH AL-BAHJAH CIREBON)
}

\author{
Artis dan Zoko Syahputra \\ Fakultas Dakwah dan Komunikasi UIN Suska Riau \\ Email: artis@uin-suska.ac.id
}

\begin{abstract}
Abstrak
Penelitian ini dilatarbelakangi oleh dakwah berbasis social network yang merupakan fenomena baru dalam dunia dakwah di era modernisasi ini. Tujuan penelitian ini adalah untuk mengetahui strategi Majelis Dakwah Al-Bahjah Cirebon berbasis social network. Jenis penelitian ini adalah deskriptif dan menggunakan pendekatan kualitatif. Informan penelitian berjumlah 6 (enam) orang. Pengumpulan data dilakukan melalui observasi, wawancara dan dokumentasi yang kemudian hasil data tersebut dianalisis dengan teknik perbandingan tetap (constant comparative method). Penelitian ini menemukan bahwa strategi dakwah Majelis Dakwah Al-Bahjah Cirebon berbasis social network telah tersistem dengan baik. Juru dakwah ( $\left.d a^{\prime} i\right)$ dalam kegiatan ini adalah Abuya Yahya Zainul Ma'arif sebagai $d a$ ' $i$ utama dan didukung oleh $d a$ ' $i$ lainnya di Tim Dakwah Al-Bahjah. Pemetaan kondisi umat (mad'u) di social network dilakukan melakukan pengklasifikasian terhadap pengguna sosial media kalangan anak-anak, remaja dan dewasa. Perumusan materi dakwah (maddah) meliputi akidah, ibadah dan muammalah yang termaktub didalam Al-Qur'an, Hadits maupun Ijma' ulama. Ditambah dengan materi-materi fenomenal atau tranding topic yang berkembang. Penyampaian materi dakwah ( $m a w d u$ ') lebih cenderung menggunakan metode bil-qalam dan metode bil-lisan yang sesuai untuk dakwah berbasis social network.
\end{abstract}

Keywords: Strategi Dakwah, Social Network, Majlis Dakwah al-bahjah 


\section{Pendahuluan}

Seiring perkembangan zaman pada abad ke-21 telah terjadi sindrom globalisasi. ${ }^{1}$ Pertama ditandai dengan masuknya teknologi yang kemudian dilanjutkan pada penggunaan internet dan berbagai aplikasinya. Media sosial (sosial network) merupakan lanjutan dari arus globalisasi yang menghubungkan seluruh lapisan masyarakat melalui dunia maya (cyberspace). Terkhusus di Indonesia, pengaruh sindrom globalisasi ini telah merambah dengan sangat cepat dan luas. Kemajuan teknologi ini tentu akan berimbas baik jika dimanfaatkan untuk kebaikan pula. Salah satu bentuk kebaikan itu adalah kegiatan penyiaran syari'at Islam. Sungguh akan sangat bermanfaat apabila gerakan dakwah juga masuk ke dalam kehidupan dunia maya.

Dari fenomena perkembangan kehidupan masyarakat tersebut, sekarang dapat dilihat begitu banyak juru dakwah bahkan lembaga dakwah yang berusaha masuk ke dalam dunia maya (cyberspace) dan melaksanakan kegiatan dakwah didalamnya. Mereka menyusun beragam strategi yang tetap bertujuan pada terealisasikannya misi dakwah. Salah satu diantara para aktivis dakwah dunia maya tersebut adalah seperti yang dilakukan oleh Majelis Dakwah Al-Bahjah yang berpusat di Cirebon. Berangkat dari fenomena tersebut penulis ingin melakukan analisis lebih lanjut melalui artikel ini dengan mengajukan pertanyaan bagaimana Strategi Dakwah Berbasis Social Network yang dilakukan oleh Majelis Dakwah AlBahjah Cirebon?

\section{Social Network untuk Dakwah}

Social network atau sosial media adalah sebuah media online dimana para penggunanya bisa dengan mudah berpartisipasi, berbagi dan menciptakan isi meliputi blog, jejaring sosial, wiki, forum dan dunia virtual. Facebook, Twitter, Youtube dan sebagainya merupakan bentuk

\footnotetext{
${ }^{1}$ A. Muis, Komunikasi Islami(Bandung: PT Remaja Rosdakarya, 2001), hlm. 131.
}

media sosial yang paling umum digunakan oleh masyarakat di seluruh dunia. Pendapat lain mengatakan bahwa social network (media sosial) adalah media online yang mendukung interaksi sosial. Media sosial menggunakan teknologi berbasis web yang mengubah komunikasi menjadi dialog interaktif. Andreas Kaplan dan Michael Haenlein mendefinisikan social network atau media sosial sebagai "sebuah kelompok aplikasi berbasis internet yang membangun di atas dasar ideologi dan teknologi Web 2.0, dan yang memungkinkan penciptaan dan pertukaran user-generated content". ${ }^{2}$

Dalam suatu proses dakwah, seorang juru dakwah ( $\left.d a^{\prime} i\right)$ dapat menggunakan berbagai sarana atau media. Salah satu media tersebut adalah dengan memanfaatkan keberadaan social network yang saat ini merupakan aplikasi-aplikasi yang sangat diminati oleh khalayak. Dewasa ini, dapat dilihat bahwa telah banyak $d a$ ' $i$ baik individu maupun organisasi dakwah yang melakukan kegiatan dakwahnya dengan memanfaatkan social network sebagai media dalam berdakwah. Salah satu unsur keberhasilan dalam berdakwah adalah kepandaian seorang $d a{ }^{\prime} i$ dalam memilih dan menggunakan sarana atau media yang ada. $^{3}$

Dakwah melalui social network dinilai sangat efektif dan potensial dengan berbagai alasan, diantaranya ${ }^{4}$ (1) Mampu menembus batas ruang dan waktu dalam sekejap dengan biaya dan energi yang

\footnotetext{
${ }^{2}$ Wisnu Iray, "Pengertian Sosial Media, Sosial Network, Peran dan Fungsinya", dalam https://www.facebook.com/notes/wisnuiray/pengertian-social-media-social-network-peranserta-fungsinya/10151963078035205 (Diakses pada tanggal 06 April 2015 pukul 20.39 WIB).

${ }^{3}$ Adi Sasono, dkk, Solusi Islam atas Problematika Umat: Ekonomi, Pendidikan dan Dakwah (Jakarta: Fauzan, 1998), 154.

${ }^{4}$ Ade Setiawan, "Dakwah dalam Cyber Media (Social Network)" dalam http://adesmedia.blogspot.com/2013/02/dakwahdalam-cyber-mediasosial-network.html (Diakses pada tanggal 02 Mei 2015 pukul 21.39 WIB).
} 
relatif terjangkau. (2) Pengguna jasa internet setiap tahunnya meningkat drastis, ini berarti berpengaruh pula pada jumlah penyerap misi dakwah. (3) Para pakar dan ulama yang berada dibalik media dakwah via social network bisa lebih konsentrasi dalam menyikapi setiap wacana dan peristiwa yang menuntut status hukum syar'i. (4) Dakwah melalui social networktelah menjadi salah satu pilihan masyarakat. Berbagai situs dan mereka bebas memilih materi dakwah yang mereka sukai, dengan demikian pemaksaaan kehendak bisa dihindari. (5) Cara penyampaian yang variatif telah membuat dakwah Islamiyah via social networkbisa menjangkau segmentasi yang luas.

Media dakwah (wasilah) sejatinya merupakan alat yang dipergunakan unutk menyampaikan materi dakwah (ajaran Islam) kepada mad'u. ${ }^{5}$ Salah satu diantaranya adalah social network, dan dalam media ini terdapat beberapa kelabihan. Ada kelebihan social network di internet sebagai media dakwah dibandingkan media dakwah yang lain, internet memiliki tiga keunggulan; pertama, karena sifatnya yang never turnoff (tidak pernah dimatikan) dan unlimited access (dapat diakses tanpa batas). Internet memberi keleluasaan kepada penggunanya untuk mengakses dalam kondisi dan situasi apapu; karena internet merupakan tempat yang tepat bagi mereka yang ingin berdiskusi tentang pengalaman spiritual yang mungkin tidak rasional dan bila dibawa pada forum yang biasa akan mengurangi keterbukaannya; sebagian orang yang memiliki keterbatasan dalam komunikasi sering kali mendapat kesulitan guna mengatasi dahaga spiritual mereka.

\section{Strategi Dakwah melalui Social Network}

Saat ini kehidupan manusia berada pada zona mabuk teknologi. ${ }^{6}$ Perkembangan teknologi saat ini tidak

${ }^{5}$ Ali Aziz, Ilmu Dakwah Edisi Revisi, 39.

${ }^{6}$ Husni Thamrin, Ed, Kutubkhanah: Jurnal Penelitian Sosial Keagamaan, Vol 11 (Pekanbaru: LPPM UIN Suska Riau, 2008), 59. dapat dibantah lagi. Dunia digital seolah sudah menjadi trend masyarakat terkini. Meskipun teknologi digital sangat membantu dan meringankan para pemakainya (user) akan tetapi teknologi manual masih dibutuhkan dan tidak untuk ditinggalkan secara total. Banyak media yang digunakan untuk sarana berdakwah, seperti: Televisi, Radio, Koran, Majalah dan sekarang yang sedang populer adalah Internet, dimana salah satu keunggulan di dalamnya adalah dengan adanya social network.

Banyak hal yang akan didapatkan dengan berdakwah melalui social network di internet. Tentunya tidak bisa dilakukan dengan bebas dan keras menyuarakan pendapat, sebab ada etika dan peraturan tersendiri meskipun di dunia maya (cyber space). Ini sejalan dengan prinsip dakwah Islamiyah, bahwa dalam berdakwah harus selalu dengan perkataan mulia (qoulul hasan), bukan dengan cercaan dan katakata kasar. Esensi dakwah tidak hanya sekedar berorasi atau hanya berkata-kata saja, akan tetapi berdakwah juga harus dengan memberikan uswah khasanah ${ }^{7}$. Pada intinya, apabila perkataan dan tindakan seorang $d a{ }^{\prime} i$ sesuai dengan apa yang dilakukannya maka akan banyak pula yang akan mengikutinya. Hamzah Ya'cub menjelaskan dakwah secara umum sebagai sebuah pengetahuan yang mengajarkan teknik menarik perhatian orang guna mengikuti suatu ideologi dan pekerjaan tertentu. Sementara dakwah khusus menurutnya adalah mengajak umat manusia dengan hikmah kebijaksanaan untuk mengikuti petunjuk Allah SWT dan Rasul-Nya. ${ }^{8}$ Teknik untuk menarik perhatian khalayak tersebut diantaranya dengan memasukkan nilai-nilai dakwah kedalam fenomena yang disukai khalayak tersebut dan salah satunya adalah social network.

\footnotetext{
${ }^{7}$ Uswatun Hasanah adalah teladan atau tauladan yang baik (mulia).

${ }^{8}$ Hamzah Ya'cub, Publistik dan Islam(Bandung: Diponogoro, 2001), 9.
} 
Berdakwah melalui sosial media (social network) di internet tergolong cukup mudah dan sangat praktis. Tidak hanya jangkauannya yang sangat luas, internet juga menghilangkan batas-batas rasisme, golongan, agama dan lainnya sehingga internet menjadi media bebas untuk menuangkan pemikiran seseorang dalam sebuah tulisan dan video serta tidak terbatas oleh waktu. Ulasan pembahasannya pun akan lebih gamblang, mengena dan dapat ditelaah pembacanya kapanpun dan dimana pun mereka berada. Jadi, untuk mengulas sebuah permasalahan yang banyak terjadi dimasyarakat, seorang $d a$ ' $i$ harus memiliki wawasan yang luas serta pengalaman baik bersifat pribadi atau pengalaman yang didapatkan dari orang lain. Bahkan dengan berdakwah melalui internet yang salah satunya memanfaatkan social network, juru dakwah bisa mendapatkan ribuan bahkan jutaan mad'u. ${ }^{9}$ Dalam memperluas dakwah, tidak ada salahnya kalau memanfaatkan social network yang telah berkembang pesat saat ini. Social network menjadi salah satu media paling efektif untuk menyalurkan bakat atau pemikiran karena internet digunakan dan diakses secara global oleh seluruh manusia yang ada di muka bumi ini.

$\begin{array}{ccc}\text { Secara } & \text { umum dakwah yang } \\ \text { dilakukan } & \text { dengan } & \text { memanfaatkan }\end{array}$ keberadaan social network merupakan bagian dari dakwah bil-lisan dan dakwah bil-qalam. $^{10}$ Dakwah bil-lisan seperti rekaman ceramah yang diunggah ke sosial media dan dakwah bil-qalam seperti

\footnotetext{
${ }^{9}$ Fadil Ibnu Ahmad, Dakwah Online: Asyiknya Meraup Pahala di Dunia Maya, 24.

${ }^{10}$ Dakwah bil-lisan adalah dakwah yang dilaksanakan melalui lisan,yang dilakukan antara lain dengan ceramah, khutbah, pidato, diskusi, nasihat dan lain-lain. Sedangkan dakwah bil-qalam adalah dakwah melalui tulisan yang dilakukan dengan keahlian menulis di media massa seperti surat kabar, majalah, buku maupun internet. Lihat Sayyid Muhammad Alwi Al-Maliki Al-Hasani, AlQudwah Al-Hasanah fi Manhaj Ad-Da'wah, Penterjemah: Samsul Munir Amin (Jakarta: Amzah, 2006), xiv-xv.
}

artikel-artikel Islami maupun obrolan online yang bernilai dakwah. Dengan melakukan dakwah secara online, juru dakwah tidak perlu bersusah payah mengundang orang untuk hadir dan memasang spanduk di sana sini, cukup hanya dengan bermodalkan komputer yang terkoneksi dengan internet, kemudian menulis atau merekam pesan-pesan dakwah dan selajutnya disebarkan.Pada hakekatnya ada cara lain yang bisa disampaikan dan ini merupakan strategi dalam melakukan dakwah berbasis social network, yaitu ${ }^{11}$ : (1) Dengan menggunakan fasilitas website seperti yang telah dilakukan oleh banyak organisasi Islam maupun tokoh-tokoh ulama. Berdakwah dengan menggunakan fasilitas ini dianggap lebih fleksibel dan luas. (2) Dengan menggunakan fasilitas Facebook, Twitter, Yuotube, dan sebagainya kemudian mengajak diskusi keagamaan atau mengirim pesan-pesan moral kepada seluruh anggotanya. (3) Dengan menggunakan fasilitas chatting yang memungkinkan untuk berinteraksi secara langsung. (4) Dengan cara tulisan yang diakses di sosial media dan nantinya disebarluaskan agar para komunitas dunia maya (cyber space) bisa membacanya.

Keberadaan internet sebagai media dakwah sudah bukan lagi pada tataran wacana. Seharusnya para ulama, $d a{ }^{\prime} i$ dan para pemimpin-pemimpin Islam mulai menyadari dan segera melakukan langkahlangkah strategis untuk menjaga dan mentarbiyah generasi-generasi muda kita agar siap dan matang dalam menghadapi serangan-serangan negatif dari media internet. Hal ini dilakukan demi sebuah perjuangan bagi masyarakat terkhusus masyarakat muslim. Secara umum, masyarakat sekarang telah berada pada tatanan masyarakat kontemporer, dimana masyarakat kontemporer adalah masyarakat yang dalam kehidupannya dan perilakunya tidak lagi mempertimbangkan

${ }^{11}$ Lihat Fadil Ibnu Ahmad, Dakwah Online: Asyiknya Meraup Pahala di Dunia Maya, 25. 
tanah air, warna kulit, bahasa, agama, adat istiadat dan budaya. ${ }^{12}$ Paradigma ini lah yang harus terus dilestarikan oleh para juru dakwah, sebab Islam pun tidak pernah membedakan hal-hal tersebut.

Sebuah langkah yang baik telah banyak dilakukan oleh ulama-ulama di timur tengah dan para cendekiawan Islam di Eropa dan Amerika yang menyambut media internet sebagai senjata dakwah. Langkah-langkah untuk berdakwah melalui internet dapat dilakukan dengan membuat jaringan-jaringan tentang Islam, diantaranya: cyber-muslim atau cyberdakwah, Situs Dakwah Islam, YoutubeIslam atau IslamTube, Website, Blog dan jaringan sosial seperti: Facebook dan twitter. Masing-masing cyber tersebut menyajikan dan menawarkan informasi Islam dengan berbagai fasilitas dan metode yang beragam variasinya. ${ }^{13}$

\section{Juru Dakwah (Da'i) di Social Network}

Berdasarkan wawancara dengan Romli, menyatakan bahwa Majelis Dakwah Al-Bahjah sendiri bukanlah pelaku pertama dalam pelaksanan kegiatan dakwah berbasis social network karena juga dibant oleh orang yang ahli dibidang network. Melihat begitu besarnya peluang yang ada maka kegiatan dakwah di dunia maya ini menjadi salah satu prioritas dalam dakwah untuk progres ke depannya. Perencanaan dan penyusunan strateginya harus dilakukan dengan professional agar kegiatan dakwah ini tidak menjadi bayangan semata. Juru dakwah Majelis Dakwah Al-Bahjah yang menjadi sumber utamanya adalah pengasuh Majelis Dakwah Al-Bahjah yaitu Abuya Yahya Zainul Ma'arif.

Lebih jauh dari pada itu, Yoga mengatakan bahwa Tim Dakwah Al-

\footnotetext{
${ }^{12}$ Lihat Masduki, Humanisme Spiritual: Paradigma Pengembangan Masyarakat Islam dalam Filsafat Sosial Hossein Nasr (Jakarta: Referensi, 2014), 45.

${ }^{13}$ Ade Setiawan, "Dakwah dalam Cyber Media (Social Network)" dalam http://adesmedia.blogspot.com/2013/02/dakwahdalam-cyber-mediasosial-network.html (Diakses pada tanggal 02 Mei 2015 pukul 21.39 WIB).
}

Bahjah Cirebon terdiri dari beberapa orang yang memiliki tugas masing-masing dalam melakukan dakwah di dunia maya ini. Terlepas dari semua tugas yang diamanahkan, setiap anggotanya tentu saling bahu-membahu dalam semua tugas yang harus dilakukan. Inilah yang menjadi salah satu faktor penting dalam merumuskan atau menyusun rencana dakwah melalui social network. Sebab setiap orang tentu memiliki argumentasi dan sudut pandang tersendiri dalam berbagai hal, dan dari sini semua gagasan serta ide yang masuk akan disatukan dalam sebuah rumusan untuk menempuh kegiatan dakwah tersebut.

Masih berkenaan dengan juru dakwah dalam kegiatan dakwah berbasis social network yang dilakukan oleh Majelis Dakwah Al-Bahjah, Yoga menambahkan bahwa da'i utama yang memberikan pesan ajaran Islam terfokus kepada Abuya Yahya seorang. Tim Dakwah yang ada hanya bertugas untuk mengabadikan segala pesan dakwah beliau yang dimuat dalam bentuk tulisan maupun rekaman (gambar dan video) yang kemudian dikemas sesuai dengan jejaring sosial yang akan digunakan. Romli menambahkan lagi, suatu waktu bisa saja terjadi penambahan subjek dakwah atau da'i yang memberikan dakwahnya, seperti saat ada Ulama, kalangan Habaib maupun Kyai yang datang ke Majelis Dakwah AlBahjah untuk menyampaikan ceramahnya. Akan tetapi, hal ini sangat jarang terjadi dikarenakan kedatangan da'i lainnya ke Majelis Dakwah Al-Bahjah hanya dalam momen-momen tertentu seperti Hari Besar Islam dan sebagainya, sehingga da'i utama dalam kegiatan dakwah berbasis social network ini hanya Abuya Yahya saja.

\section{Pemetaan Kondisi Umat (Mad'u) di Social Network}

Dalam berdakwah, salah satu hal yang juga tidak kalah penting untuk diperhatikan adalah mad'u atau sasaran dakwah itu sendiri. Sekalipun dakwah telah dikemas dengan sangat baik dan menarik, namun keberhasilan dakwah itu 
sendiri akan sangat minim pencapaiannya jika tidak tepat sasaran apalagi sampai tidak menetapkan tujuan, walau secara umum telah diketahui jika tujuan dakwah itu untuk menyeru manusia kepada jalan Allah SWT. Menurut Ketua Tim Dakwah Al-Bahjah, sasaran (mad'u) dalam kegiatan dakwah di dunia maya ini adalah seluruh lapisan masyarakat yang berhubungan langsung dengan social network dalam kehidupannya, sebab saat ini kehidupan manusia dalam kesehariannya sangat dekat dengan jaringan cyber space. Selanjutnya, tujuan dari dakwah melalui social network ini juga sama dengan tujuan dakwah pada umumnya, yaitu meneruskan misi yang dibawa Rasulullah SAW sebagai perintah Allah SWT.

Senada dengan hal di atas, Medi juga mengatakan sasaran dari aktifitas dakwah berbasis social network yang dilakukan oleh Majelis Dakwah Al-Bahjah Cirebon tidak hanya terfokus pada satu kalangan masyarakat, sebab semua lapisan masyarakat sebagian besar telah terhubung dengan kehidupan sosial di dunia maya. Walau tidak bisa dinafikan bahwa mayoritas pengguna jejaring sosial adalah kalangan remaja. Akan tetapi, dakwah yang dilakukan tetap menuju kepada semua lapisan yang ada, sebab itu merupakan peluang dakwah yang memang harus dimanfaatkan dengan aksi atau tindakan. Ada kelebihan tersendiri terhadap sasaran dakwah jika melakukan kegiatan dakwah di dunia maya ini, yaitu jangkauan sasaran dakwah atau mad'u jauh lebih luas jika dibandingkan dengan berdakwah di mimbar-mimbar, media cetak dan juga forum kajian-kajian Islam.

Menurut Mafahim, pemetaan kondisi mad'u (sasaran dakwah) di dunia maya tetap diklasifikasikan sesuai dengan jenjang kalangan yang secara garis besar terbagi atas tiga kalangan. Pertama, kalangan anak-anak yang sekarang telah banyak bersentuhan dengan social network, kedua kalangan remaja yang memang merupakan pengguna social network terbanyak dan ketiga adalah kalangan dewasa yang saat ini juga mulai masuk dalam kehidupan di social network. Pengklasifikasian tersebut dilakukan berdasarkan jenjang usia para pengguna sosial media, walau tidak bisa dipastikan dengan kongkrit berapa saja umurnya, akan tetapi klasifikasi tersebut juga tetap mengacu pada fase pertumbuhan manusia yang memang setiap manusia akan mengalaminya. Namun demikian, saat kegiatan dakwah dilakukan, klasifikasi itu tidak terlalu difokuskan karena penyampaian dakwah akan sampai kepada mereka secara keseluruhan. Dari kenyataan ini lah Tim Dakwah Al-Bahjah melancarkan kegiatan dakwah secara universal. Terlepas dari itu, dalam hal-hal tertentu terkadang dakwah juga ditujukan pada kalangan-kalangan tertentu pula. Seperti obrolan (chatting) di Facebook, pada bagian ini mad'u diberikan kesempatan untuk bertanya langsung melalui obrolan yang tersedia dan kebanyakan yang bertanya adalah kalangan remaja sehingga pada saat itu yang menjadi sasaran dakwah adalah kalangan remaja.

Selanjutnya bisa terjadi percakapan online pada akun jejaring sosial lainnya seperti komentar yang masuk di Youtube terhadap video dakwah yang di-upload. Komentar yang masuk bisa saja berupa tanggapan maupun kritikan, pertanyaanpertanyaan sampai kepada pandangan yang berbeda, ini semua terangkum dalam kolom komentar yang memang tersedia sebagai bentuk efek dari video yang diupload. Komentar maupun tanggapan yang masuk memang bukan merupakan target utama dalam pelaksanaan kegiatan dakwah berbasis social network ini, akan tetapi bentuk interaksi yang terjadi tersebut menjadi satu bagian yang memang tidak bisa terpisahkan dalam pelaksanaan kegiatan dakwah apapun bentuknya dan apapun salurannya.

Saat dakwah dilancarkan melalui Youtube, maka dominannya dakwah ditujukan kepada semua orang atau semua 
kalangan yang bisa mengakses jejaring sosial tersebut. Namun, pada saat-saat tertentu dakwah juga ditujukan kepada beberapa kalangan dengan cara mengemas video dengan kategori materi yang tentunya masing-masing kalangan mempunyai kesesuaian tersendiri. Saat rekaman video yang diunggah berbicara mengenai permasalahan keluarga seperti hukum nikah, perceraian, hak-hak suami istri dan sebagainya, maka sasarannya adalah kalangan dewasa walau tidak dinyatakan secara langsung. Selanjutnya saat rekaman video yang di-upload berisikan pesan-pesan kenakalan remaja, maka sasaran utamanya adalah kalangan remaja itu sendiri, namun video ini juga secara tidak langsung ditujukan kepada orang-orang tua agar bisa lebih peka mengawasi anak-anaknya terhadap pergaulan bebas di kalangan remaja. Maka pada intinya, pemetaan kondisi mad'u di dunia maya tidak bisa ditentukan secara sepihak karena dakwah yang disampaikan akan tersentuh langsung kepada semua pengguna jejaring sosial, namun Majelis Dakwah Al-Bahjah hanya mencoba mengklasifikasikan sasaran dakwah ke beberapa kalangan agar dakwah itu bisa dikemas secara sesuai dan pas.

Yoga selaku selaku anggota Tim Dakwah Al-Bahjah mengatakan bahwa tujuan dakwah di dunia maya merupakan tujuan suci yang secara garis besar untuk kemaslahatan umat. Yoga juga menambahkan bahwa sasaran dakwah melalui social network adalah merekamereka yang menggunakan social network itu sendiri. Mengenai status agama yang tentu beragam, tidak menjadi alasan dakwah melalui sosial media ini harus diberikan lini batasan. Sebab secara global, dakwah sejatinya tidak hanya tertuju kepada umat Islam itu sendiri, melainkan juga tertuju kepada semua orang walau beragama non muslim. Islam hadir sebagai petunjuk bagi semua manusia yang tidak dikekang oleh koridor perbedaan keyakinan di kalangan manusia. Dakwah melalui social network ini juga sangat diharapkan dapat menyentuh golongan non muslim yang mungkin akan sangat sulit jika dilakukan melalui mimbar-mimbar maupun Majelis Ta'lim.

\section{Perumusan Materi Dakwah (Maddah) Berbasis Social Network}

Materi dakwah merupakan salah satu bagian terpenting dalam pelaksanaan kegiatan dakwah. Sebab grafik efektifitas dakwah akan semakin meningkat jika materi yang disajikan bisa tepat pada sasarannya. Dakwah yang professional pada dasarnya harus bisa untuk membaca peta keadaan dan kemudian menentukan materi yang sesuai.

Hasil wawancara dengan Romli yang juga menjadi koordinator Tim Dakwah AlBahjah, didapatkan bahwa materi dakwah yang disampaikan lebih menjurus pada materi umum yang biasa disampaikan oleh para Ustadz saat berceramah, akan tetapi kegiatan dakwah di dunia maya ini juga banyak memuat materi-materi lain yang kesemuanya masih terangkum dalam ajaran Islam dan terhimpun dalam AlQur'an, Al-Hadist maupun Ijma' para ulama.

Menurut Riski, materi dakwah yang disampaikan Majelis Dakwah Al-Bahjah dapat dikelompokkan menjadi empat bagian, pertama materi amaliyah yang lebih kepada sosial kemasyarakatan, kedua materi yang berkenaan dengan event keIslaman seperti Tahun Baru Islam dan sebagainya, ketiga renungan Buya Yahya untuk menggugah hati dan keempat materi ceramah-ceramah majelis umum. Randi menambahkan bahwa materi yang disampaikan dalam majelis umum Buya Yahya meliputi materi Tafsir Al-Qur'an yang dilaksanakan setiap hari Sabtu dan materi Kajian Kitab Riyadhussolihin setiap hari minggu. Setiap materi yang disampaikan oleh Buya Yahya akan didokumentasikan menjadi video maupun tulisan yang kemudian dilakukan proses editing agar kemasan dan tampilannya lebih rapi serta menarik, selanjutnya akan langsung diunggah ke dunia maya 
memalui beberapa akun jejaring sosial (social network).

Masih berkenaan dengan materi dakwah yang disampaikan oleh Majelis Dakwah Al-Bahjah melaui social network, Mafahim menambahkan bahwa secara garis besarnya materi dakwah yang disampaikan lebih dominan kepada pembahasan mengenai sosial kemasyarakatan. Seperti hukum dalam keluarga, pergaulan sosial (hablumminannas) dan sebagainya. Tidak menutup kemungkinan juga materi yang disampaikan akan lebih terfokus pada topik tertentu saat ada fenomena-fenomena tertentu pula. Misalnya, timbul fenomena mengenai sekelompok aliran yang menamai diri mereka sebagai Ahmadiyah dimana masyarakat pada umumnya tidak terlalu mengetahui siapa mereka. Maka di sini akan diberikan penjelasan agar pertanyaan-pertanyaan yang timbul di masyarakat bisa terjawab dan kemaslahatan umat lebih terjaga serta terhindar dari perpecahan maupun adu domba antar kelompok (firqoh). Saat terjadi perbedaan pendapat atau pernyataan penting berkenaan dengan Islam yang sedang menjadi perbincangan hangat (tranding topic), maka ini akan menjadi fokus materi dakwah yang akan disampaikan oleh Majelis Dakwah AlBahjah saat berdakwah melalui social network.

Medi juga mengatakan, bahwa pada intinya materi yang disampaikan ke para pengguna sosial media adalah materimateri yang disampaikan oleh Buya Yahya pada saat berceramah, mengisi pengajian maupun majelis ilmu sampai kepada artikel-artikel Islam yang beliau tulis. Selebihnya, materi dakwah yang disampaikan akan menyesuaikan dengan perkembangan yang terjadi dan juga permintaan dari para pengguna jejaring sosial, bisa dengan mengirimkan e-mail, bertanya melalui obrolan (chatting) dan juga komentar pada akun jejaring sosial yang digunakan.

\section{Pemilihan Situs Jejaring Sosial (Wasilah) yang Digunakan}

Media dakwah atau pun saluran yang menjadi penghubung kegiatan dakwah merupakan poin yang tidak kalah penting dari beberapa unsur dakwah lainnya. Juru dakwah tidak hanya harus memiliki keahlian cakap dalam beretorika dan menguasai beragam ilmu, akan tetapi harus juga memiliki kemampuan mengoperasikan berbagai media yang ada baik media cetak, media elektronik dan sebagainya. Selanjutnya, para juru dakwah juga dituntut untuk mampu memilih media yang sesuai serta tepat sasaran. Media yang digunakan akan berpengaruh pada tersampaikannya materi tersebut dengan baik dan sesuai perencanaan atau tidak.

Menurut Mafahim, kegiatan dakwah melalui social network yang dilakukan Majelis Dakwah Al-Bahjah sangat digencarkan dengan berusaha merambah ke berbagai jejaring sosial yang ada. Tenaga ahli yang dimiliki Tim Dakwah Al-Bahjah telah cukup mumpuni untuk mengoperasikan berbagai akun jejaring sosial dalam pelaksanaan kegiatan dakwah berbasis social network ini. Sejauh ini, prioritas utama yang digunakan oleh Majelis Dakwah Al-Bahjah untuk berdakwah di dunia maya cukup dipusatkan dengan akun jejaring sosial Facebook. Akun fans page yang dibuat dijadikan sebagai motor penggerak utama, sebab Facebook memiliki dua kelebihan, yakni bisa mengunggah konten-konten Islami dan juga video-video yang juga bertujuan untuk dakwah. Di samping itu, Youtube juga menjadi salah satu akun jejaring sosial yang diperhatikan, karena melalui Youtube dapat diunggah videovideo ceramah dan kajian Buya Yahya yang dapat dikemas secara audiovisual dan tentu akan lebih menarik perhatian para mad'u yang ada di dunia maya. Selanjutnya, akun jejaring sosial lain yang digunakan adalah Twitter. Namun karena keterbatasan aplikasi yang ditawarkan oleh Twitter, maka akun Twitter yang dibuat dimaksudkan untuk menjadi pendukung 
akun-akun lainnya karena dakwah melalui social network ini diharapkan dapat merambah kepada semua jejaring sosial yang ada. Salah satu fungsi akun Twitter adalah melanjutkan posting-an dari beberapa akun lain, misalnya posting-an mengenai kajian Buya Yahya maupun jadwal ceramah Buya Yahya .

Terkait mengenai akun jejaring sosial yang digunakan, Riski mengatakan bahwa akun Facebook digunakan sebagai akun utama yang nantinya akan diikuti oleh akun-akun lainnya. Konten-konten yang dipublikasikan di Facebook selanjutnya akan di-posting pada akun jejaring sosial lainnya. Facebook juga menyediakan sarana untuk melakukan obrolan (chatting) yang membuat mad'u bisa langsung bertanya tanpa khawatir diketahui oleh pengguna lainnya, sebab terkadang ada mad'u yang ingin banyak mengkaji mengenai Islam namun sedikit malu dan gengsi untuk mengungkapkan. Terbukti, di akun Facebook yang dimiliki Majelis Dakwah Al-Bahjah, hampir setiap hari masuk pesan-pesan obrolan (chatting) yang menandakan bahwa sarana ini menjadi pilihan yang cukup diminati oleh para pengguna sosial media untuk memperdalam pengetahuan mereka tentang ajaran agama Islam.

Terlepas dari pada hal itu, Riski menambahkan bahwa admin (operator akun) yang bekerja harus memiliki keahlian dan kecakapan yang baik agar dapat menanggapi serta merespon setiap keinginan mad'u dengan baik pula. Admin juga bertugas untuk langsung menjawab pertanyaan maupun komentar yang masuk jika itu masih berkutat dalam cakrawala umum, seperti masalah sosial, jadwal pengajian Buya Yahya, diskusi universal dan sebagainya. Akan tetapi, jika pertanyaan atau komentar yang masuk telah berkenaan dengan Akidah dan masalah-masalah pokok dalam Islam, maka hal ini akan langsung disampaikan kepada Buya Yahya untuk dijawab maupun ditanggapi, kemudian hasilnya akan diberikan kepada pengguna yang bertanya atau yang memberikan komentar tadi. Di sini lah peran admin yang bertugas pada akun Facebook harus sigap dan cermat dalam memilah berbagai respon yang hadir. Kesigapan dan kemampuan Tim Dakwah Al-Bahjah dirasa telah memenuhi standarisasi untuk mengoperasikan social network, tidak hanya keahlian dalam mengoperasikan jejaring sosial yang ada, tetapi juga sigap dalam merespon segala tanggapan yang hadir sebagai hasil balik dari kegiatan dakwah berbasis social network ini.

Riski juga mengatakan bahwa kemampuan untuk mengoperasikan akun jejaring sosial merupakan poin penting, selain dari pada agar dakwah bisa tersampaikan, keahlian yang dibutuhkan juga untuk melindungi dan menjaga privasi akun dari segala gangguan maupun hambatan yang datang, untuk itu lah pelatihan IT (Information Technology) kerap kali dilakukan oleh Majelis Dakwah Al-Bahjah guna meningkatnya keahlian Tim dakwahnya. Tidak jarang akun-akun yang bernafaskan Islam menjadi sasaran empuk bagi oknum-oknum (para hackers) tertentu untuk melakukan pembajakan. Apapun yang menjadi alasan mereka melakukan pembajakan memang hanya mereka yang mengetahui dan umat Islam tidak boleh berburuk sangka (suudzon), namun dalam pelaksanaan kegiatan dakwah ini, pengamanan ekstra tetap harus dilakukan guna meminimalisir hal-hal yang tidak diinginkan dari keberadaan para hackers tersebut. Tim Dakwah Al-Bahjah cukup memiliki keahlian dalam memberikan pengamanan (security account) terhadap jejaring sosial yang digunakan. Ditambah lagi, Buya Yahya selaku pendiri dan pengasuh Majelis Dakwah Al-Bahjah terus memberikan wejangan agar Tim Dakwah Al-Bahjah tidak melakukan pembalasan dengan cara yang serupa. Keburukan yang pihak lain lakukan terhadap kegiatan mulia ini harus ditanggapi dengan cara yang bijak sesuai dengan tuntunan Al-Qur'an dan Al-Hadits. 
Riski mengatakan bahwa dorongan dakwah yang dilakukan oleh Majelis Dakwah Al-Bahjah semata-mata merupakan wujud dari ketaatan terhadap perintah Allah SWT yang membuat kekhawatiran terhadap segala gangguan bisa dihadapi dan diformulasikan menjadi motivasi. Dakwah yang dilakukan melalui social network juga merupakan kegiatan dakwah yang pasti mendapat hambatan dalam berbagai takaran, tinggal bagaimana hambatan-hambatan yang hadir tersebut disikapi dengan respon yang baik tanpa harus bersikeras melakukan perlawanan.

Lebih jauh dari pada itu, Romli mengatakan bahwa Facebook dipilih sebagai akun jejaring sosial utama karena Facebook hadir lebih dulu daripada akun jejaring sosial lainnya sehingga jumlah penggunanya pun tidak bisa dinafikan sangat banyak bahkan menjadi mayoritas di sosial media. Ditambah lagi fasilitas yang ditawarkan di dalamnya juga memberikan kesempatan yang semakin luas bagi para pegiat dakwah di dunia maya.

Untuk akun Youtube sendiri, sebenarnya juga menjadi akun yang cukup penting karena mampu menggunggah video dengan durasi yang sangat panjang dan mampu dinikmati para pengguna secara audio maupun visual. Video yang di-upload terdiri dari dua klasifikasi, pertama video kajian maupun ceramah Buya Yahya secara full (penuh), kedua video kajian atau ceramah Buya Yahya yang di-cut (dipotong) menjadi cuplikancuplikan khusus, artinya dalam cuplikan tersebut terdapat penekanan pada materi atau topik tertentu sehingga mad'u yang melihat bisa lebih terfokus pada hal tersebut. Hal ini dilakukan mengingat tidak semua pengguna jejaring sosial memiliki banyak waktu untuk melihat video dengan durasi yang panjang.

Selanjutnya, Romli menambahkan bahwa akun Twitter dan akun lainnya yang merupakan pendatang baru di dunia maya menjadi pilihan sebagai akun pendukung karena ternyata juga ramai diminati oleh para pengguna sosial media. Hal ini dilakukan dengan maksud agar dakwah yang diberikan mampu dirasakan oleh para pengguna semua akun, sebab para pengguna akun tersebut tentu mempunyai akun jejaring sosial yang digemari dan masing-masing tentu berbeda.

\section{Penyampaian Dakwah (Mawdu') di Social Network}

Dakwah sesungguhnya bertujuan untuk menyampaikan ajaran-ajaran tauhid yaitu Islam kepada seluruh umat manusia dengan cara penyampaian (metode) yang benar, menyeru kepada yang ma'ruf dan mencegah dari yang munkar. Dakwah yang dilakukan dengan memanfaatkan kemajuan teknologi sebagai medianya merupakan inovasi yang dikembangkan oleh para juru dakwah guna memperbesar peluang kesuksesan dakwah yang dilakukan. Fenomena dakwah berbasis social network merupakan hal yang baru saja terjadi di era modernisasi sekarang ini.

Berdasarkan hasil wawancara kepada Muhammad Romli selaku ketua Tim Dakwah Majelis Dakwah Al-Bahjah Cirebon, metode dakwah (mawdu') melalui social network dirumuskan dengan cara melakukan pemantauan terhadap perkembangan dunia maya (cyber space) yang kemudian dilanjutkan dengan mengadakan diskusi kecil bersama anggota tim untuk menentukan kapan dakwah dilakukan dan apa materi yang akan disampaikan. Hal ini dimaksudkan agar kegiatan dakwah yang akan dilangsungkan nantinya bisa lebih efektif dan sesuai harapan. Dakwah di sosial media juga mempertimbangkan jejaring sosial yang digunakan. Sampai saat ini, Majelis Dakwah Al-Bahjah memang telah menggunakan sebagian besar jejaring sosial yang ada, namun yang cukup menjadi perhatian utama adalah kegiatan dakwah melalui Facebook, Youtube dan Twitter. Selain dari pada tiga jejaring sosial tadi, Tim Dakwah Al-Bahjah tetap merambah ke jejaring sosial lainnya, seperti Instagram, Paht, Line dan sebagainya yang dimaksudkan sebagai 
akun pendukung. Hal ini dilakukan agar cara penyampaian dakwahnya pun bisa terus diinovasikan.

Menurut Mafahim, keberadaan cyber space di tengah kehidupan umat manusia yang merupakan salah satu imbas dari kemajuan zaman adalah sebuah peluang besar bagi aktifis dakwah untuk melaksanakan misi dakwahnya. Kegiatan dakwah melalui social network harus dirancang dengan pertimbanganpertimbangan khusus yang berangkat dari berbagai aspek sosial dan agama. Dalam melaksanakan kegiatan dakwah di dunia maya, kegiatan dakwah yang akan dilakukan dimulai dengan membaca peta keadaan (kondisi sosial di dunia maya) yang kemudian disusun metode dakwah seperti apa yang bisa dilakukan di sana. Selanjutnya, kegiatan dakwah dilakukan dengan seoptimal mungkin, mengenai hasil dari kegiatan dakwah itu tentu merupakan hak priogatif Allah SWT, sebab hidayah hanya datang dari Allah SWT dan para juru dakwah hanya melakukan kewajiban untuk meneruskan misi Rasulullah SAW yaitu menyebarluaskan ajaran agama Islam.

Mafahim menambahkan bahwa kegiatan dakwah melalui social network merupakan sebuah terobosan baru yang sejatinya memang harus dilakukan oleh para pegiat dakwah, sebab tantangan dan metode dakwah di masa kini tidak lagi sama secara keseluruhan dengan tantangan dan metode dakwah yang digunakan pada masa Rasulullah SAW. Setiap zaman dapat dikatakan mempunyai ciri khas dan tantangan tersendiri, dan pada zaman millenium ini kecanggihan teknologi dapat dikatakan sebagai pendamping proses kehidupan umat manusia sehingga manusia itu sendiri sangat dekat dengan teknologi. Di sini juga lah para juru dakwah harus jeli melihat celah yang ada dan cakap untuk memilih metode dakwahnya guna mengembangkan medan dakwah dari masa ke masa.

Sama halnya dengan Yoga, yang juga mengatakan penyusunan rencana dakwah dalam memilih metode dakwah melalui social network dilakukan dengan cara bertahap, mulai dari memetakan keadaan, kemudian disusun bentuk dakwah yang ingin dilakukan sampai kepada kegiatan dakwah itu direalisasikan. Sejauh gerakan yang telah dilakukan, metode dakwah yang digunakan cenderung kepada metode lisan dan tulisan, sebab memang kedua elemen tersebut yang banyak tersedia dalam berbagai situs jejaring sosial.

Hal menarik lainnya disampaikan oleh Medi. Medi mengatakan bahwa saat ini Tim Dakwah Al-Bahjah telah memiliki berbagai macam peralatan dan perlengkapan yang menunjang dan memperkaya metode dakwah yang dapat digunakan dalam kegiatan dakwah berbasis social network ini. Lengkapnya fasilitas teknologi dan ruangan tersendiri menjadi faktor pendukung bagi Tim Dakwah Al-Bahjah untuk melancarkan aksi dakwahnya. Di ruangan tersebut semua anggota Tim Dakwah berkumpul setiap harinya dan melakkukan diskusidiskusi guna merumuskan bentuk penyampaian dakwah yang akan dilakukan.

Yoga yang merupakan ahli editing di Tim Dakwah Al-Bahjah mengatakan bahwa dukungan yang hadir telah sangat cukup bagi kegiatan dakwah berbasis social network ini, karena pihak Manajemen pun senantiasa memperbaharui segala kebutuhan dan perlengkapan yang diinginkan. Dengan segala fasilitas yang memadai ini lah Tim Dakwah Al-Bahjah merasa semakin bersemangat.

\section{Pengelolaan Feedback dalam Dakwah Berbasis Social Network}

Kegiatan dakwah pada esensinya harus di-manage dengan baik, mulai dari tempat sampai kepada waktu pelaksanaannya. Berdawkah di sosial media memberikan peluang bagi aktifis dakwah sebab sosial media bisa diakses setiap hari bahkan setiap waktu. Selanjutnya, feedback yang terjadi sebagai 
interaksi dalam berdakwah harus pula dikelola dengan sebaik mungkin. Berdasarkan wawancara dengan Mafahim, mengatakan bahwa waktu pelaksanaan kegiatan dakwah di dunia maya memiliki jadwal yang telah disusun. Namun, untuk saat ini jadwalnya masih dalam penyesuaian dengan bagian Manajemen di Al-Bahjah, mengingat Al-Bahjah juga mempunyai stasiun Televisi dan Radio tersendiri yang membuat Al-Bahjah harus membagi waktu serta jadwal dengan sangat rapi dan tersusun. Frekuensi dakwah melalui social network juga tidak bisa dipatok dengan ketentuan tertentu, lebih tepatnya kegiatan dakwah di dunia maya sampai saat ini masih bersifat kondisional yang artinya bergantung juga kepada feedback yang terjadi. Dalam prosesnya Majelis Dakwah Al-Bahjah melalui Tim Dakwahnya melakukan kegiatan dakwah dengan meng-upload, mengunggah atau pun mem-posting semua yang berkenaan dengan dakwah sesuai dengan jadwal yang telah ditentukan. Akan tetapi, bisa saja frekuensinya akan menjadi lebih banyak karena respon positif dari penghuni dunia maya itu sendiri, seperti adanya komentar yang masuk maupun adanya pertanyaan yang masuk sehingga Tim Dakwah akan bekerja lagi untuk memenuhi hal tersebut dan frekuensi dakwahnya menjadi lebih banyak.

Randi juga ikut memberi penjelasan bahwa terkadang frekuensi dakwah melalui social network bisa sangat meningkat drastis dan terkadang bisa saja normal. Hal ini tidak bisa dipastikan, mengingat respon dari pengguna sosial media itu sendirilah yang menjadi salah satu sebab frekuensi dakwah akan meningkat. Berkenaan dengan waktu pelaksanaannya, Tim Dakwah Al-Bahjah memilih waktu-waktu tertentu saat akan berdakwah melalui social network. Waktu yang dipilih adalah pagi hari sekitar ba'da shalat Shubuh sampai waktu shalat Dhuha, karena pada waktu ini jumlah pengunjung di dunia maya bisa dikatakan sangat ramai sebab belum terlalu disibukkan oleh aktifitas keseharian. Dilanjutkan pada waktu istirahat siang atau sekitar waktu sahalat Dzuhur karena pada waktu ini pengunjung cyber space juga sangat ramai. Kemudian waktu yang paling ditargetkan adalah malam hari, mulai dari ba'da shalat 'Isya sampai waktu tidur normal. Waktuwaktu tersebut dipilih karena mempertimbangkan saat-saat sosial media ramai dikunjungi oleh para penggunanya.

Medi menambahkan bahwa frekuensi kegiatan dakwah melalui social network bisa mencapai tiga sampai empat kali dalam kurun 24 jam sehari semalam. Hal ini terlepas dari adanya komentar atau obrolan (feedback) yang terjadi dari para pengguna sosial media yang ingin menjalin komunikasi dengan Majelis Dakwah Al-Bahjah. Semakin banyak dan semakin tinggi respon yang masuk dari para pengguna sosial media, maka akan semakin meningkat pula frekuensi dakwah yang dilakukan. Bentuk pengelolaan feedback yang terjadi dilakukan dengan pertimbangan kondisional pula. Saat respon yang hadir mampu ditanggapi langsung oleh admin, maka itu akan langsung ditanggapi. Akan tetapi, saat respon yang datang dirasa merupakan topik yang penting seperti seputaran akidah atau hal pokok lainnya, maka hal ini akan langsung disampaikan langsung kepada Abuya Yahya baik secara lisan maupun tulisan. Tanggapan balik dari Abuya Yahya kemudian diteruskan oleh admin untuk disampaikan kepada pemberi respon (feedback) tadi.

\section{Kesimpulan}

Setelah disajikan dan dianalisis, dapat disimpulkan bahwa strategi dakwah Majelis Dakwah Al-Bahjah berbasis social network telah terencana dan diterapkan dengan baik walau masih memerlukan pembenahan. Juru dakwah (da'i) dalam kegiatan ini adalah Abuya Yahya Zainul Ma'arif sebagai $d a{ }^{\prime} i$ utama dan didukung oleh da'i lainnya di Tim Dakwah AlBahjah. Pemetaan kondisi umat (mad'u) di social network dilakukan dengan pengklasifikasian terhadap pengguna 
sosial media menjadi kalangan anak-anak, kalangan remaja dan kalangan dewasa. Perumusan materi dakwah (maddah) meliputi Akidah, Ibadah dan Muammalah yang termaktub di dalam Al-Qur'an, AlHadits maupun Ijma' para ulama. Ditambah dengan materi-materi fenomenal atau tranding topic sesuai dengan pembicaraan yang berkembang. Penyampaian materi dakwah (mawdu') lebih cenderung menggunakan metode bilqalam dan metode bil-lisan yang memang sesuai untuk dakwah berbasis social network. Selanjutnya pemilihan situs jejaring sosial (wasilah) dilakukan dengan pertimbangan potensi dan peluang yang ada dan ini merupakan tindakan yang bijak dalam kegiatan dakwah. Akun-akun social network yang dipilih karena dianggap potensial adalah Facebook sebagai akun utama, Youtube sebagai akun prioritas selanjutnya danTwitter serta akun lainnya sebagai akun penunjang. Pengelolaan feedback yang dilakukan dalam kegiatan dakwah ini juga telah dilakukan dengan tindakan yang cukup bijak. Respon yang hadir akan ditanggapi langsung dan kemungkinan juga akan ditanggapi oleh Abuya Yahya terlebih dahulu. Strategi dakwah Majelis Dakwah Al-Bahjah berbasis social network memang masih memerlukan pembenahan dan evaluasi, akan tetapi secara global telah tersistem dengan baik.

\section{Daftar Pustaka}

Ahmad, Amrullah, Dakwah Islam dan Perubahan Sosial,(Yogyakarta: PLP2M, 1983).

Ahmad, Fadil Ibnu, Dakwah Online:Asyiknya Meraup Pahala di Dunia Maya, (Bandung: PT. Mizan Pustaka, 2014).

Al-Baghdadi, Abdurrahman, Dakwah Islam dan Masa Depan Umat,(Bangil: AlIzzah, 1997).

Al Barry, M. Dahlan, tt.Kamus Ilmiah Populer,(Surabaya: Arkola).

Al-Hasani, Sayyid Muhammad Alwi AlMaliki.Al-Qudwah Al-Hasanah fi Manhaj Ad-Da'wah, (Jakarta: Amzah,2006).
Al-Maraghi, Ahmad Musthafa.Tafsir AlMaraghi,(Beirut: Darul Fikr, 2006).

Al-Qathani, Sa'id, Menjadi Da'i yang Sukses, (Jakarta: Qisthi Press, 2005). Jilid V.

Anis, Ibrahim, Al-Mu'jam al-Wasith, (Mesir: Dar'l Ma'arif, 1972), Jilid ke-1, cet. ke- 2.

Arifin, Anwar, Strategi

Komunikasi,(Bandung: Armico, 1989).

Arikunto, Suharsimi, Prosedur Penelitian

Suatu Pendekatan Praktik (Jakarta: Rineka Cipta, 2006 ).

As'ad Yasin, dkk, Tafsir Fi Zhilalil Qur'an, (Jakarta: Gema Insani Press,Jilid ke-14, 2004).

As, Enjang,Dasar-Dasar Ilmu Dakwah, (Bandung: PT Remaja Rosda Karya, 2009).

Aziz, Ali, Ilmu Dakwah Edisi Revisi, (Jakarta: Kencana, 2009).

Badadu JS Zain, Sutan Muhammad,Kamus Bahasa Indonesia (Jakarta: Pustaka Sinar Harapan, 1994).

Bachtiar, Wardi, Metodologi Penelitian Ilmu Dakwah (Jakarta: PT. Raja Grafindo Persada, 1997).

Bisri, Cik Hasan, Penuntun Penyusunan Rencana Penelitian dan Penulisan Skripsi, (Jakarta: Raja Grafindo Persada, 2001).

Bungin, M. Burhan, Penelitian Kualitatif: Komunikasi, Ekonomi, Kebijakan Publik dan Ilmu Sosial Lainnya, (Jakarta: Prenada Media Group, 2007).

Djaliel, Maman Abdul, Prinsip dan Strategi Dakwah, (Jakarta: Prenada Media, 1997).

Enterprise, Jubilee, Buku Pintar Internet, (Jakarta: PT. Elex Media Komputindo, 2013).

Fatah, Rohadi Abdul Fatah, Manajemen Dakwah di Era Global(Jakarta: CV. Fauzan Inti Kreasi, 2003).

Ghazali, M. Bahri, Membangun Kerangka Dasar Ilmu Komunikasi Dakwah. (Bandung: PT. Remaja Rosda Karya, 1997).

Gulo W, Metodologi Penelitian, (Jakarta: PT. Gramedia, 2004). 
Hadi, Soetrisno, Metodologi Research, Jilid I, (Yogyakarta: ANDI, 1980).

Hasjmy, A,.Dustur Dakwah Menurut AlQur'an, (Jakarta: Bulan Bintang, 1974).

Hidayat, Taufik, Lebih Dekat dengan Facebook, (Jakarta: PT Elex Media Komputindo, 2009).

Ilaihi, Wahyu Hefni, Harjani, Pengantar Sejarah Dakwah,(Jakarta:Raja Grafindo Persada, 2008).

Ilaihi, Wahyu, Komunikasi Dakwah,(Bandung: $\quad$ PT. Remaja Rosdakarya, 2010).

Kementrian Agama RI, Mushaf Al-Qur'an Terjemah, (Bandung:Insan Kamil, 2007).

Masduki, Humanisme Spiritual:

Paradigma Pengembangan Masyarakat Islam dalam Filsafat Sosial Hossein Nasr,(Jakarta: Referensi, 2014).

Muhiddin, Asep, Dakwah dalam Perspektif Alquran: Studi Kritis atas Visi, Misi, dan Wawasan, (Bandung: Pustaka Setia, 2002).

Muis , Komunikasi Islami, (Bandung: PT. Remaja Rosdakarya, 2001).

Munawir, Ahmad Warson, Kamus AlMunawir Arab-Indoensia, Cet ke-14, (Surabaya: Pustaka Progresif, 1997).

Munir, M. Metode Dakwah, ( Jakarta: Kencana,2006).

Munir, Samsul,.Ilmu Dakwah, (Jakarta: Amzah, 2009).

Nasution, Faruq,Aplikasi Dakwah dalam Studi Kemasyarakatan(Jakarta: Bulan Bintang, 1986).

Nawawi, Hadari, Metode Penelitian Bidang Sosial (Yogyakarta: Gadjah Mada University Press, 2007).

Nurhuda, Eko, Youtube:Cara Mudah Menjadi Populer dengan Internet. Yogyakarta: Andi Offset, 2012).

Nurrochman, Strategi Dakwah melalui Pemasaran Media Online pada Situs www.sahabataqsa.com, (Yogyakarta: Jurnal Skripsi, 2014).

Pimay, Awaluddin, Metodologi Dakwah Kajian Teoritis Khazanah Al-Qur'an. Semarang: Rasail, 2006).

Qutb, Sayyid, fi dhibah al Quran, (Cairo: Dar al Syuruq, Jilid IV, 1399 H/1979 M).
Ramdhani, Ahmad Mujahid, Strategi Dakwah Internet Situs www.alsofwah.or.id sebagai Sumber Informasi Islam,(Yogyakarta: Jurnal Skripsi, 2007). Rauf, Abdul Kadir Sayid Abd, Dirasah Fid Dakwah Al-Islamiyah, (Kairo: Dar ELTiba'ah Al-Ahmadiyah, cet ke-1, 1978).

Saputra, Wahidin,Pengantar Ilmu Dakwah, (Jakarta: Raja Grafindo Persada, 1978).

Sasono, Adi, dkk, Solusi Islam atasProblematikaUmat:

Ekonomi,Pendidikan dan Dakwah, (Jakarta: Fauzan, 1998).

Shihab, M. Quraish, Membumikan AlQur'an,(Bandung: Alfabeta, 2008).

Suminto, R.H. Akib,Problematika Dakwah, (Jakarta: Bulan Bintang, 1973).

Suryabrata, Sumadi, Metodologi Penelitian, (Jakarta: PT. Raja Grafindo Persada, 1995).

Suyanto, Bagong dan Sutinah, Metode Penelitian Sosia, (Jakarta: Kencana,2010).

Syukir, Asmuni, Dasar-Dasar Strategi Dakwah Islam,(Makassar: Sarwah Press,2001).

Tasmara, Toto,Komunikasi Dakwah, (Jakarta: Gaya Media Pratama).

Thamrin, Husni, Kutubkhanah: Jurnal Penelitian Sosial Keagamaan, (Pekanbaru: LPPM UIN Suska Riau, Vol 11, 2008).

Tohirin, Metode Penelitain Kualitatif, (Jakarta: Raja Grafindo Persada, 2012).

Udin, Rafi dan Djaelani, Maman Abdul,Prinsip dan Strategi Dakwah,(Jakarta: Pustaka Media, 2001).

Umar, Toha Yahya, Ilmu Dakwah, (Jakarta: Wijaya, 1971).

Yani, Ahmad, Materi Dakwah Pilihan,(Jakarta: Prenada Media Group,2006).

Yaqub, Ali Mustafa, Sejarah dan Metode Dakwah Nabi,(Jakarta: Pustaka Firdaus, 1997).

Ya'cub, Hamzah, Publistik dan Islam,(Bandung: Diponogoro, 2001).

Zainab, Siti, Harmonisasi Dakwah dan Komunikasi, (Banjarmasin: Antasari Press, 2009). 


\section{Artikel Online :}

Buya Yahya "beranda akun" dalam https://twitter.com/buya_albahjah (Diakses pada tanggal 15 November 2015).

Buya Yahya Menjawab "Menyikapi Fenomena Islam Nusantara" dalam https://www.youtube.com/watch=?XYBi

We3HirU(Diakses pada tanggal15 November 2015).

Buya Yahya "Merenungi Ciptaan AllahSWT" dalam https://www.youtube.com/watch=?Ddq82g gkg7A (Diakses pada tanggal 15 November 2015).

Fadli, Chairul. "Pengertian Social network"dalam

https://chairulfadli86.wordpress.com/tag/p engertian-social-network/ (Diakses pada tanggal 06 April 2015).

Iray, Wisnu. "Pengertian Sosial Media, Sosial Network, Peran dan Fungsinya"dalamhttps://www.facebook.co $\mathrm{m} /$ notes/wisnu-iray/pengertian-socialmedia-social-network-peran-sertafungsinya/10151963078035205 (Diakses pada tanggal 06 April 2015).

Pemerintah Kabupaten Cirebon "Profil Daerah Letak dan Keadaan Geografis" dalamhttp://www.cirebonkab.go.id/en_US/ sekilas-kab-cirebon/letak-geografis

(Diakses pada tanggal 16 Oktober 2015).

Setiawan, Ade. "Dakwah dalam Cyber Media (Social Network)" dalam http://adesmedia.blogspot.com/2013/02/da kwah-dalam-cyber-mediasosialnetwork.html (Diakses pada tanggal 02 Mei 2015).

Tim Dakwah Al-Bahjah Cirebon, "Deskripsi Singkat Fans Page Facebook"https://www2.facebook.com/M ajelis.AlBahjah.Cirebon/info?tab=page inf o (Diakses pada tanggal 28 Maret 2015).

Tim Dakwah Al-Bahjah "Profil Pergerakan Dakwah Al-Bahjah" melalui website resmi dalamhttp://albahjahonline.com/index.php/ tokoh/item/60-sebuah-perjuanganmelahirkan-generasi-mulia (Diakses pada tanggal 15 Oktober 2015).

\section{Daftar Wawancara :}

Alyoga Pratama, Anggota Tim Dakwah Al-Bahjah Cirebon.

Muhammad Romli Jamali, Ketua Tim Dakwah Al-Bahjah Cirebon.

Medi Mukhtayasar, Anggota Tim Dakwah Al-Bahjah Cirebon.

Nail Mafahim, Anggota Tim Dakwah AlBahjah Cirebon.

Randi, Anggota Tim Dakwah Al-Bahjah Cirebon.

Riski Akbar Sholeh, Anggota Tim Dakwah Al-Bahjah Cirebon. 